\title{
Numerical and experimental investigation on the transient behavior of an earth air heat exchanger in continuous operation mode
}

\author{
Yousef Belloufi ${ }^{1 *}$, Abdelhafid Brima ${ }^{1}$, Sakina Zerouali ${ }^{2}$, Rachid Atmani ${ }^{1}$, Faris Aissaoui ${ }^{1}$, Amar Rouag $^{3}$, \\ Noureddine Moummi ${ }^{1}$ \\ ${ }^{1}$ Laboratoire de Génie Mécanique LGM, BP 145.07000 University of Biskra, Algeria \\ ${ }^{2}$ Laboratoire de Modélisation des Systèmes Energétiques LMSE, BP 145.07000 University of Biskra, Algeria \\ ${ }^{3}$ Laboratoire de Génie Energétique et Matériaux LGEM, BP 145.07000 University of Biskra, Algeria
}

Email: yousef_belloufi@yahoo.fr

\begin{abstract}
The main objective of the present study is to investigate the thermal performances of an earth air heat exchanger (EAHE) under transient conditions in cooling mode. This work was performed experimentally in the University of Biskra, Algeria. For that, a PVC pipe of $53.16 \mathrm{~m}$ long and $110 \mathrm{~mm}$ diameter buried at $3 \mathrm{~m}$ depth is used. Tests of the experimental setup were carried out in continuous operation mode for 71 hours with high inlet temperatures. Besides, a mathematical model was presented for EAHE by using the finite differences method applying the energy balance equations with forced convection. In addition of the horizontal portion on soil surface, the two vertical portions of $3 \mathrm{~m}$ each one connected to the horizontal portion were considered in the modeling in order to present a fairly complete study of the EAHE. It was found that the continuous operation mode have no remarkable effect on the outlet air temperature and thus on the EAHE performances during all 71 hours. Results of the theoretical predictions were validated with the measured air temperatures along the EAHE and showed satisfactory qualitative and quantitative agreement.
\end{abstract}

Keywords: Earth Air Heat Exchanger, Cooling Mode, Continuous Operation Mode, Thermal Comfort.

\section{INTRODUCTION}

In the last decades, the world is experiencing of high consumption of electric power necessary to the air conditioning, especially in hot regions during the hot period. To reduce this consumption, we can find clean, safe and inexpensive alternative sources for air conditioning, like earth air heat exchangers (EAHE). The idea of using earth as a heat sink was known in ancient times. In about 3000 B.C., Iranian architects used wind towers and underground air tunnels for passive cooling [1-4]. The main advantages of EAHE system are its simplicity, high cooling and pre-heating potential, low operational and maintenance costs, saving of fossil fuels and related emissions [5] .

This paper examines the air conditioning tools using an EAHE (called Canadian wells or Provencal wells). It is a ventilation system designed to preheat or refresh the air using the thermal inertia of the soil. The air aspirated from the outside transits by a buried pipe at a well-defined depth on a distance $\mathrm{L}$, recovering during its path the soil energy (to heat or to cool), what allows a preheating or refreshment of the building according to the season (winter or summer).

Several experimental and theoretical researchers have developed the EAHE in the literature.

Trombe et al. [6] realized their experimentation in the south of France on an individual house; they noticed that the outside air can be conditioned even with very high temperatures. The experimental research of Thanu et al. [7] on EAHE for the thermal comfort of a building indicates that the system works and possesses a high efficiency during the summer period. Ghosal et al $[8,9]$ presented the modeling of an earth to air heat exchanger with a greenhouse. Shukla et al. [10] developed a thermal model for heating of greenhouse by using different combinations of inner thermal curtain, an EAHE and geothermal heating. Some authors [11-16] have developed theoretical studies with different analytical models of the horizontal heat exchanger on the soil surface. They concluded that in order to increase the performances of the EAHE, it is required to take into account the following parameters: i) the length and diameter of the pipe, ii) the burial depth of the underground heat exchanger and iii) the thermal properties of the soil namely (thermal conductivity $\lambda_{\text {soil }}$ and specific heat $\mathrm{C}_{\mathrm{p}}$ ). Mihalakakou et al. [17], Lee and Strand [18] presented a parametric study to investigate the effect of pipe length, pipe radius, air flow rate and depth of the buried pipe on the overall performance of the EAHE under various conditions in cooling mode. Brum et al. [19], who have developed a new numerical approach (called reduced model) to obtain the fluid dynamics and thermal behavior of the EAHE, their results are validated with literary archives. Vaz et al. [20] presented an experimental study of an annual cycle realized in the south of Brazil. A numerical solution of the conservation equations is 
performed with commercial code 'FLUENT' based on the finite volume method. Thiers et al. [21] considered that only part of the soil is influenced by the heat exchanger, and take into account the interaction of several tubes by comparing the distance between them and the depth of penetration defined by Hollmuller [15]. Barakat et al [22] developed a Transient one-dimensional model for predicting the impact of main geometrical and dynamical parameters including tube length, inner tube diameter and inlet air velocity on the performance of the EAHE system. Ozgener et al [23] designed and installed an EAHE in Turkey for the determination and evaluation of thermal properties of the heat exchanger. An Average total heat exchanger thermal resistance was estimated to be $0.021 \mathrm{~K}-\mathrm{m} / \mathrm{W}$ as a constant value under steady state condition. Mathur et al [24] studied soil thermal saturation and self recovery ability under intermittent and continuous operation modes of EAHE. They were developed a numerical model using ANSYS 14.5, its results have been validated experimentally through a full scale setup. They found that the soil temperature can be recovered in both intermittent and continuous operation modes by employing natural heat conduction and convection (where inlet air temperature in night hours is lower than soil temperature). Vaz et al [25] concluded that the soil temperature around the buried pipe gets affected by the continuous operation of EAHE. They developed a correlation between the soil and buried pipe temperature variation using linear regression model. Bansal et al [26] studied the effect of soil thermal conductivity and time period of continuous operation of EAHE on its thermal performance. In this way, a three different types of soil thermal conductivities of $0.52 \mathrm{w} / \mathrm{m}^{\circ} \mathrm{c}, 2$ $\mathrm{w} / \mathrm{m}^{\circ} \mathrm{c}$ and $4 \mathrm{w} / \mathrm{m}^{\circ} \mathrm{c}$ are compared. It was concluded that the thermal performance of EAHE deteriorates with prolonged operation and soil having poor thermal conductivity. Mathur et al [27] investigated thermal performance of an EAHE under transient conditions for three different soil thermal conductivities considering three operating modes. In mode 1 (12 h of continuous operation), mode 2 (cycle of $12 \mathrm{~h}$ of intermittent operation i.e $60 \mathrm{~min} \mathrm{ON}$ and $20 \mathrm{~min} \mathrm{OFF}$ ) and mode 3 (cycle of $12 \mathrm{~h}$ of intermittent operation i.e $60 \mathrm{~min} \mathrm{ON}$ and $40 \mathrm{~min}$ OFF). The outlet air temperatures have been numerically determined using CFD software Fluent V 6.3. it was concluded that EAHE system with higher soil thermal conductivity $(1.28 \mathrm{w} / \mathrm{m} \mathrm{k})$ can be operated continuously (mode 1). Bansal et al [28] introduced a new concept named 'Derating Factor' for evaluating thermal performance of EAHE under transient operation conditions using experimental and CFD modeling with Fluent software. The derating Factor is affected by air flow velocity inside the EAHE, pipe geometry, ambient conditions and type of operation (intermittent or continuous). They concluded that for better thermal performance, it was advisable to operate the EAHE system in soil with higher thermal conductivity. Yang et al [29] evaluated the thermal performance of EAHE, they proposed an analytical model in periodically fluctuating thermal environment without using 'penetration radius' to confine the distance of heat diffusion in soil. The presented model costs much less time than CFD simulation and provides solutions with high accuracy. It was found that the buried depth, pipe length and mass flow rate are important parameters for evaluating the performance of EAHE. Chel et al [30] evaluated the dynamic thermal performance if building integrated with water heat exchanger (WAHE) and EAHE by using transient system simulation (TRNSYS). Their results show that WAHE and EAHE had a reduction of the annual heating consumption of $66 \%$ and $7 \%$ respectively. Hatraf et al [31] presented a parametric study for designing an EAHE and evaluating its thermal performance. They showed that the efficiency of the EAHE depends of on buried depth of pipe and pipe dimensions. The pipe material exceptionally does not affect the thermal performance of the EAHE. Misra et al [32] investigated experimentally the thermal performance of hybrid EAHE system in four different modes by integrating active and passive systems. Inside the room, a temperature of $25^{\circ} \mathrm{C}$ is remained constant during each mode. Mode 1 (air conditioner alone supplies the conditioned air to the room without functioning EAHE), mode 2 (air conditioner supplies conditioned air to room and $100 \%$ conditioned air from EAHE is also delivered directly to the room), mode 3 (like mode 2, but exceptionally the EAHE is functioned for cooling the condenser tubes of air conditioner) and mode 4 (air conditioner supplies the conditioned air to the room, 50\% conditioned air from EAHE is injected to the room directly and remaining $50 \%$ air is used for condenser cooling). It was found that the third mode reduced $18 \%$ of electrical energy consumption in comparison with first mode and an increasing of $16 \%$ in electrical energy consumption in fourth mode as compared to the first mode.

The aim of this study is to clarify the effect of the continuous operation mode, soil thermal conductivity and air flow velocity on the thermal performance of the EAHE. Unlike previous studies which examined the horizontal portion of the EAHE, our contribution in this work is to present a fairly complete theoretical study in all parts of the EAHE (verticals and horizontal portions) Fig. 1. The experimental measurements were realized in the region of Biskra for three days in continuous operation mode and used to validate the proposed numerical model. The region of Biskra is typical climate for air cooling in hot period. Where the air temperature in this arid region recorded in July and August with an afternoon average temperature of $47^{\circ} \mathrm{C}$.

\section{MODELING}

The following assumptions are used to simplify the modeling: i) From a defined depth $\delta$ the temperatures remain constant in the soil, ii) soil far than the EAHE keeps a constant temperature during the heat exchange, iii) convective heat transfer coefficient is constant along the pipe, iv) longitudinal conduction and soil moisture are neglected and v) perfect contact between the pipe and the soil surrounding.

We divide the EAHE into three portions (vertical portion I, horizontal portion II and vertical portion III) as mentioned in the Fig.1.

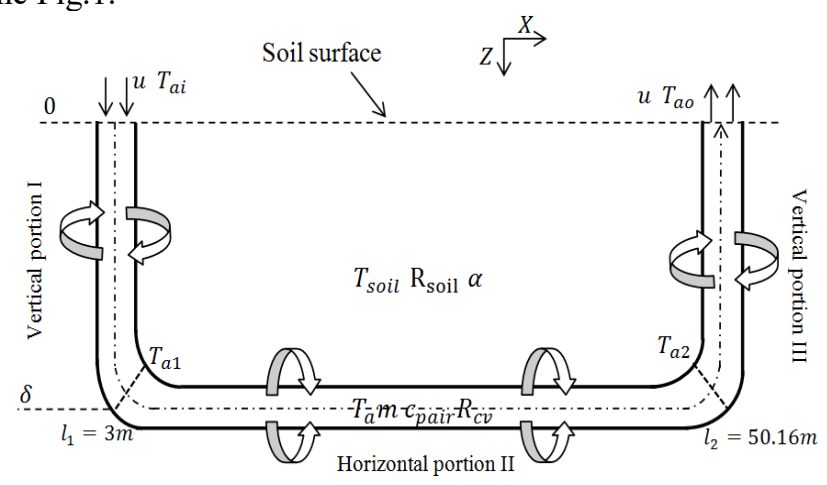

Figure 1. Descriptive scheme of the EAHE. 


\subsection{Soil temperature around the EAHE}

The soil temperature around vertical portions I and III in the vertical coordinate is based on the resolution of heat equation in unsteady state [33]

$\frac{\partial^{2} T_{\text {soil }}}{\partial z^{2}}=\frac{1}{\alpha} \frac{\partial T_{\text {soil }}}{\partial t}$

The following boundary conditions are used for solving eq.(1)

$$
\begin{aligned}
& T_{\text {soil }}(z=0)=T_{p} \\
& T_{\text {soil }}(z=\delta)=T_{i} \\
& T_{\text {soil }}(t=0)=T_{i}(z)=a z+b
\end{aligned}
$$

The unknown constants $\mathrm{a}$ and $\mathrm{b}$ can be determined by substituting the boundary conditions (2) and (3) in eq. (4). When $\delta$ is the depth of buried pipe, $T_{i}$ is the soil temperature at depth $\delta$ and is the soil surface temperature, where we ensure the heat flow continuity between the soil and the ambient air to define it [34].

$T_{p}=\frac{\lambda_{\text {soil }}}{\lambda_{\text {soil }}-\delta h} T_{i}-\frac{\delta h}{\lambda_{\text {soil }}-\delta h} T_{a i}$

The distribution of the soil temperature eq. (6) is then obtained by imposing the boundary conditions (2), (3) and (4).

$$
T_{\text {soil }}(z)=\left(T_{p}-T_{i}(z)\right)\left(1-e r f\left(\frac{z}{2 \sqrt{\alpha t}}\right)\right)+T_{i}(z)
$$

\subsection{Temperature of the air along the EAHE}

The portions I and III are buried vertically to the soil surface, it assembled to the horizontal portion II Fig. 1 which is buried sufficiently deep in the soil, to keep the soil temperature $T_{\text {soil }}$ constant and less sensitive to external climatic conditions. The energy balance equations between two sections distant of $\Delta l$ inside the portions I, II and III Fig. 2 can be written as follow

$$
\begin{aligned}
& m c_{\text {pair }} \frac{D T_{a}}{D t}=q_{1}-q_{2}-q_{3} \\
& m c_{\text {pair }} \frac{D T_{a}}{D t}=q_{1}-q_{2}+q_{3}^{\prime}
\end{aligned}
$$

where eq. (7) represnts to the energy balance equation of the portions I and II Figs. $2 \mathrm{a}$ and $2 \mathrm{~b}$ respectively and eq. (8) represnts to the vertical portion III Fig. $2 \mathrm{c}$ where $q_{3}=-q_{3}$ ' so eqs. (7) and (8) have the same result. From eqs. (7) and (8), we obtain

$$
m c_{\text {pair }}\left(\frac{\partial T_{a}}{\partial t}+u \frac{\partial T_{a}}{\partial z}\right)=-\left.\lambda_{\text {air }} s \frac{\partial T_{a}}{\partial z}\right|_{l}+\left.\lambda_{\text {air }} s \frac{\partial T_{a}}{\partial z}\right|_{l+\Delta l}+\frac{\left(T_{\text {soil }}-T_{a}\right)}{R_{\text {total }}}
$$

where $u$ is the air velocity inside the pipe, $s=\pi \cdot r_{1}^{2}$ is the internal section of the pipe.

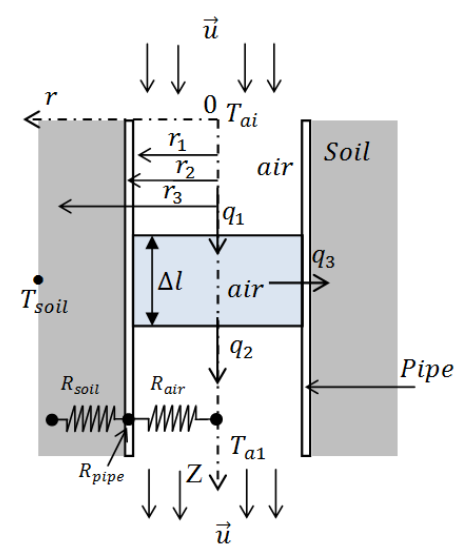

(a)

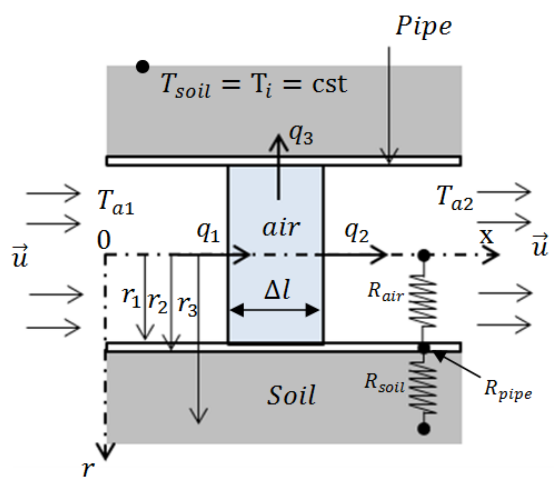

(b)

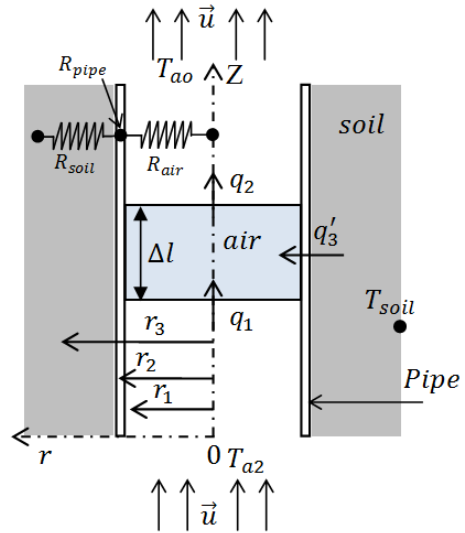

(c)

Figure 2. Descriptive scheme of the EAHE: a) vertical portion I, b) horizontal portion II, c) vertical portion III.

The total thermal resistance $\left(R_{\text {total }}\right)$ is composed of the soil conductive resistance $\left(R_{\text {soil }}\right)$, the pipe resistance $\left(R_{\text {pipe }}\right)$ and the air convective resistance $\left(R_{c v}\right)$.

$$
R_{\text {total }}=R_{\text {soil }}+R_{\text {pipe }}+R_{c v}
$$

We know that $r_{3}(t)=\sqrt{\frac{\alpha . t}{\pi}}$ is the adiabatic layer radius of the soil surrounding the pipe and $h=\left(\begin{array}{ll}N u & k\end{array}\right) / 2 \quad r_{l}$ is the convective heat transfer coefficient of the flowing air inside the EAHE, where $N u=0.023 \operatorname{Re}^{0.8} \operatorname{Pr}^{0.3}$ [35] is the Nusselt number and $R e=\rho v / \mu$ is the Reynolds number.

Taking into account the fact that convection dominates conduction, eq. (9) reduces to.

$$
\rho s c_{\text {pair }}\left(\frac{\partial T_{a}}{\partial t}+u \frac{\partial T_{a}}{\partial z}\right)=\frac{\left(T_{\text {soil }}-T_{a}\right)}{R_{\text {itotal }}}
$$

$R_{\text {itotal }}$ is the total thermal resistance per unit length.

$\frac{\partial T_{a}}{\partial t}=-u \frac{\partial T_{a}}{\partial z}+\frac{\left(T_{\text {soil }}-T_{a}\right)}{\gamma}$

with $\gamma=\rho \pi r_{l}^{2} c_{\text {pair }} R_{\text {itotal }}$

Choosing the following initial conditions for all parts of EAHE in order to solve eq. (12).

$T_{a}(L=0)=T_{a i}$, which is the measured air temperature at the inlet of EAHE. 
$T_{a}\left(L=l_{l}\right)=T_{a l}$, which is the air temperature at the outlet of vertical portion $\mathrm{I}$.

$T_{a}\left(L=l_{2}\right)=T_{a 2}$, which is the air temperature at the inlet of vertical portion III.

$T_{a}(t=0)=T_{\text {soil }},[36-38]$

To solve eq. (12), implicit finite differences used to discretize both space and time domains eq. (13). Space domain discretizes to some elements $\mathrm{N}_{\mathrm{x}}=5316$ with an element size $\Delta x=0.01 \mathrm{~m}$ and time domain discretizes to a number of time steps $\mathrm{N}_{\mathrm{t}}$ with a time step $\Delta \mathrm{t}=15 \mathrm{sec}$. Fig. (3) presents the EAHE configuration and the discrete domain.

$\mathrm{T}_{\infty}$

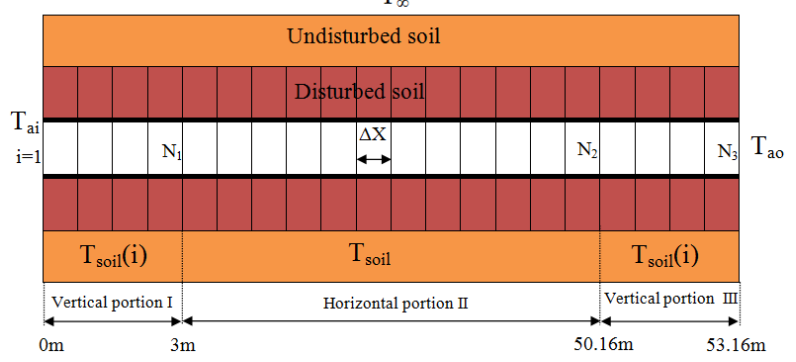

Figure 3. Discretization of EAHE domain.

$\frac{1}{\Delta t}\left[T_{i, j+1}-T_{i, j}\right]=-\frac{u}{2 \Delta l}\left[T_{i+1, j+1}-T_{i-1, j+1}\right]-\frac{1}{\gamma} T_{i, j+1}+\frac{T_{\text {soil }}}{\gamma}$

$T_{i, j}+\frac{\Delta t}{\gamma} T_{\text {soil }}=-\frac{u \Delta t}{2 \Delta l} T_{i-1, j+1}+\left(\frac{\Delta t}{\gamma}+1\right) T_{i, j+1}+\frac{u \Delta t}{2 \Delta l} T_{i+1, j+1}$

The discretized form in eq. (14) was implemented in FORTRAN language where Thomas method was used to find the air temperatures in all portions of the EAHE.

The soil temperature $T_{\text {soil }}$ is considered constant in horizontal portion II and variable in vertical portions I and III eq. (6).

\subsection{Derating factor}

Thermal performance of EAHE is basically defined as the amount of cooling which can be produced. EAHE operating under steady state condition is taken as reference case for comparing the thermal performance of EAHE is transient conditions. Temperature drops obtained under transient conditions are used to determine the derating factor which is known as the ratio of deterioration in thermal performance under transient conditions to the thermal performance for steady state condition. Derating factor can be written as follows [39]:

$$
D F=\frac{\left(T_{\text {inlet }}-T_{\text {outlet }}\right)_{\text {transient state }}}{\left(T_{\text {inlet }}-T_{\text {outlet }}\right)_{\text {steady state }}}
$$

\subsection{EAHE thermal efficiency}

The efficiency of the EAHE is defined as the ratio of air temperature drop and temperature difference between soil and inlet air temperature:
$\varepsilon=\frac{\left(T_{\text {outlet }}-T_{\text {inlet }}\right)}{\left(T_{\text {soil }}-T_{\text {inlet }}\right)}$

\section{EXPERIMENTAL SETUP}

Soil temperature depends on several parameters, such as: the soil nature, the thermal conductivity, the heat quantity absorbed by the soil from the solar radiation and the ambient temperature. In the region of Biskra it is known that at a depth of $3 \mathrm{~m}$, the soil temperature remains fairly constant and less sensitive to external climatic conditions [40].

This work (fig .4) has been performed in the Laboratory of Mechanical Engineering LGM at Biskra University (latitude of $34^{\circ} 48^{\prime} \mathrm{N}$, longitude of $5^{\circ} 44^{\prime} \mathrm{E}$ [41]). The temperatures of the air were measured at distances of $0,3.63 \mathrm{~m}, 7.69 \mathrm{~m}, 11.73 \mathrm{~m}$, $16.04 \mathrm{~m}, 20.07 \mathrm{~m}, 24.12 \mathrm{~m}, 26.37 \mathrm{~m}, 29.07 \mathrm{~m}, 33.10 \mathrm{~m}, 37.01$ $\mathrm{m}, 38.86 \mathrm{~m}, 40.82 \mathrm{~m}, 45.10 \mathrm{~m}, 48.80 \mathrm{~m}$ (the outlet of horizontal portion II) and $53.16 \mathrm{~m}$ (the outlet of vertical portion III and EAHE) from the pipe entrance. Fig. 5 illustrates the location of thermocouples in the buried pipe. The air temperatures inside the EAHE were recorded every 15 mins during three days in continuous operation mode in August 2013, and presented in Tables 2, 3 and 4.

The EAHE shown in Fig. 4 consists of one PVC pipe of $110 \mathrm{~mm}$ diameter and a total length of $53.16 \mathrm{~m}$, the serpentine pipe buried at $3 \mathrm{~m}$ depth, with $2 \mathrm{~m}$ spacing in $2 \%$ slope. It occupies an area of $85 \mathrm{~m}^{2}$. A sink is provided at the outlet of the horizontal portion II to evacuate the condensed water. A central acquisition unit provided by National Instrument, connected by 16 RTD temperature sensors to measure the air temperature along the buried pipe. The air velocity inside the pipe is managed by a volumetric flow rate extractor, this latter have low electric power consumption $(120 \mathrm{~W})$. The main characteristics of the system and the technical characteristics of measuring instruments are reported in Tables 1 and 2 respectively.

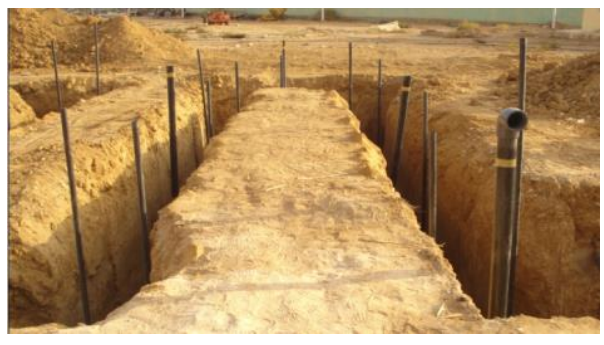

Figure 4. General view of the EAHE.

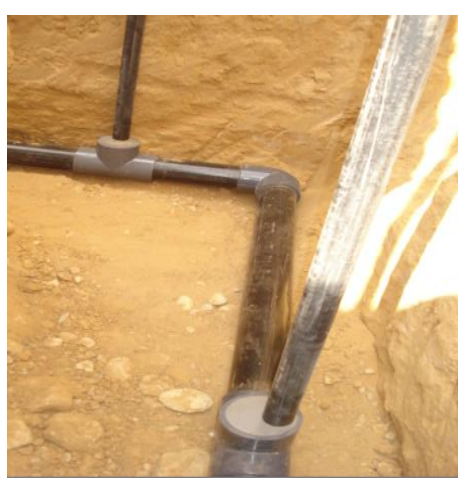

Figure 5. Location of RTD temperature sensors in the buried pipe. 
Table 1. Various system parameters.

\begin{tabular}{lc}
\hline System & Value \\
\hline Soil temperature at depth $\delta\left(T_{i}\right)$ & $26^{\circ} \mathrm{C}$ \\
Depth of buried pipe $(\delta)$ & $3 \mathrm{~m}$ \\
Air specific heat cpair & $1000 \mathrm{~J} /\left(\mathrm{Kg} .{ }^{\circ} \mathrm{C}\right)$ \\
Air density $(\rho)$ & $1.2 \mathrm{Kg} / \mathrm{m} 3$ \\
Soil thermal conductivity $\left(\lambda_{\text {soil }}\right)$ & $1.25 \mathrm{~W} /\left(\mathrm{m} .{ }^{\circ} \mathrm{C}\right)$ \\
Thermal conductivity of pipe $\left(\lambda_{p}\right)$ & $0.17 \mathrm{~W} /\left(\mathrm{m} .{ }^{\circ} \mathrm{C}\right)$ \\
Air velocity inside the pipe $(u)$ & $3.5 \mathrm{~m} / \mathrm{s}$ \\
Inner radius of the pipe $\left(r_{l}\right)$ & $55 \mathrm{~mm}$ \\
Outer radius of the pipe $\left(r_{2}\right)$ & $57.5 \mathrm{~mm}$ \\
\hline
\end{tabular}

Table 2. Technical characteristics of measuring instruments.

\begin{tabular}{|c|c|c|c|}
\hline Instrument & $\begin{array}{c}\text { Measuring } \\
\text { range }\end{array}$ & Accuracy & Resolution \\
\hline $\begin{array}{c}\text { RTD } \\
\text { temperature } \\
\text { sensors }\end{array}$ & $\begin{array}{l}-50 \text { to } \\
200^{\circ} \mathrm{C}\end{array}$ & - & $10^{-5}{ }^{\circ} \mathrm{C}$ \\
\hline $\begin{array}{l}\text { propeller } \\
\text { anemometer } \\
\text { LV100 }\end{array}$ & $\begin{array}{c}\text { From } 0.3 \\
\mathrm{~m} / \mathrm{s} \text { to } 35 \\
\mathrm{~m} / \mathrm{s}\end{array}$ & $\begin{array}{c}\text { From } 0.3 \text { to } 3 \mathrm{~m} / \mathrm{s}: \pm \\
3 \% \text { of reading } \\
0.1 \mathrm{~m} / \mathrm{s} \\
\text { From } 3,1 \text { to } 35 \mathrm{~m} / \mathrm{s}: \pm \\
1 \% \text { of reading } \pm \\
0.3 \mathrm{~m} / \mathrm{s}\end{array}$ & $0,01 \mathrm{~m} / \mathrm{s}$ \\
\hline
\end{tabular}

Table 3. Variation of air temperature along the EAHE (04-05/08/2013).

\begin{tabular}{ccccccccccc}
\hline $\begin{array}{c}\text { Length of } \\
\text { pipe }(\mathrm{m})\end{array}$ & $10: 30$ & $12: 30$ & $14: 30$ & $15: 15$ & $16: 30$ & $18: 30$ & $20: 30$ & $01: 30$ & $05: 30$ \\
\cline { 2 - 9 } After 1h & After 3h & After 5h & After 5:45h & After 7h & After 9h & After 11h & After 16h & After 20h \\
\hline inlet & 36.31 & 39.32 & 41.27 & 43.56 & 42.39 & 41.80 & 38.34 & 34.25 & 32.13 \\
3.63 & 35.98 & 38.25 & 39.84 & 41.58 & 40.98 & 40.42 & 37.26 & 33.95 & 32.26 \\
7.69 & 33.91 & 35.50 & 36.65 & 37.71 & 37.61 & 37.39 & 35.30 & 33.00 & 31.79 \\
11.73 & 32.13 & 33.23 & 34.06 & 34.63 & 34.80 & 34.86 & 33.68 & 32.16 & 31.38 \\
16.04 & 31.37 & 32.26 & 32.98 & 33.50 & 33.59 & 33.70 & 32.72 & 31.59 & 30.94 \\
20.07 & 30.71 & 31.38 & 31.94 & 32.33 & 32.47 & 32.61 & 31.92 & 31.12 & 30.64 \\
24.12 & 29.87 & 30.36 & 30.79 & 31.05 & 31.18 & 31.34 & 30.92 & 30.42 & 30.09 \\
26.37 & 29.72 & 30.13 & 30.50 & 30.71 & 30.84 & 31.01 & 30.67 & 30.27 & 30.00 \\
29.07 & 29.52 & 29.87 & 30.17 & 30.33 & 30.45 & 30.61 & 30.37 & 30.09 & 29.89 \\
33.10 & 29.12 & 29.40 & 29.65 & 29.78 & 29.88 & 30.02 & 29.84 & 29.67 & 29.53 \\
37.01 & 28.64 & 28.84 & 29.03 & 29.12 & 29.20 & 29.33 & 29.23 & 29.15 & 29.07 \\
38.86 & 28.45 & 28.63 & 28.80 & 28.87 & 28.95 & 29.08 & 28.99 & 28.94 & 28.87 \\
40.82 & 28.28 & 28.45 & 28.60 & 28.67 & 28.74 & 28.86 & 28.79 & 28.76 & 28.71 \\
45.10 & 27.91 & 28.00 & 28.10 & 28.13 & 28.18 & 28.25 & 28.23 & 28.27 & 28.27 \\
48.80 & 27.77 & 27.87 & 27.95 & 27.99 & 28.04 & 28.12 & 28.09 & 28.13 & 28.13 \\
53.16 & 30.24 & 30.19 & 30.29 & 30.36 & 30.52 & 30.69 & 30.76 & 30.29 & 29.98 \\
\hline
\end{tabular}

Table 4. Variation of air temperature along the EAHE (05-06/08/2013).

\begin{tabular}{rcccccccccc}
\hline \multirow{2}{*}{$\begin{array}{l}\text { Length } \\
\text { pipe }(\mathrm{m})\end{array}$} & of & $10: 30$ & $12: 30$ & $14: 30$ & $15: 45$ & $16: 30$ & $18: 30$ & $20: 30$ & $01: 30$ & $05: 30$ \\
\cline { 2 - 9 } inlet & After 25h & After $27 \mathrm{~h}$ & After $29 \mathrm{~h}$ & After 30:15h & After 31h & After 33h & After 35h & After 40h & After 44h \\
\hline 3.63 & 38.53 & 41.43 & 42.32 & 43.92 & 42.92 & 41.51 & 38.42 & 33.60 & 29.71 \\
7.69 & 37.80 & 39.62 & 40.84 & 42.01 & 41.55 & 40.22 & 37.42 & 33.54 & 30.45 \\
11.73 & 35.45 & 36.42 & 37.54 & 38.22 & 38.13 & 37.49 & 35.61 & 32.91 & 30.71 \\
16.04 & 33.47 & 34.01 & 34.84 & 35.23 & 35.36 & 35.17 & 34.05 & 32.31 & 30.88 \\
20.07 & 32.65 & 32.93 & 33.71 & 34.02 & 34.15 & 34.05 & 33.14 & 31.79 & 30.59 \\
24.12 & 31.87 & 31.99 & 32.63 & 32.87 & 32.98 & 33.01 & 32.35 & 31.38 & 30.46 \\
26.37 & 30.89 & 30.92 & 31.39 & 31.55 & 31.66 & 31.76 & 31.34 & 30.71 & 30.07 \\
29.07 & 30.39 & 30.66 & 31.06 & 31.20 & 31.29 & 31.41 & 31.07 & 30.57 & 30.04 \\
33.10 & 29.90 & 29.85 & 30.13 & 30.20 & 30.27 & 30.40 & 30.22 & 29.97 & 29.66 \\
37.01 & 29.32 & 29.23 & 29.44 & 29.50 & 29.55 & 29.67 & 29.56 & 29.43 & 29.22 \\
38.86 & 29.09 & 29.00 & 29.19 & 29.23 & 29.30 & 29.41 & 29.31 & 29.21 & 29.03 \\
40.82 & 28.89 & 28.81 & 28.98 & 29.01 & 29.07 & 29.18 & 29.10 & 29.03 & 28.87 \\
45.10 & 28.37 & 28.30 & 28.39 & 28.40 & 28.44 & 28.51 & 28.49 & 28.50 & 28.44 \\
48.80 & 28.22 & 28.15 & 28.24 & 28.26 & 28.29 & 28.36 & 28.33 & 28.35 & 28.28 \\
53.16 & 29.96 & 30.21 & 30.26 & 30.45 & 30.54 & 30.67 & 30.73 & 30.30 & 29.95 \\
\hline
\end{tabular}


Table 5. Variation of air temperature along the EAHE (06-07/08/2013).

\begin{tabular}{ccccccccccc}
\hline $\begin{array}{c}\text { Length of } \\
\text { pipe }(\mathrm{m})\end{array}$ & $10: 30$ & $12: 30$ & $14: 30$ & $15: 30$ & $16: 30$ & $18: 30$ & $20: 30$ & $01: 30$ & $08: 30$ \\
\cline { 2 - 8 } & After 49h & After 51h & After 53h & After 54h & After 55h & After 57h & After 59h & After 64h & After 71h \\
\hline inlet & 40.98 & 45.24 & 46.14 & 48.87 & 47.96 & 45.31 & 40.24 & 34.92 & 37.87 \\
3.63 & 39.83 & 42.66 & 43.57 & 44.94 & 44.70 & 43.05 & 38.89 & 34.68 & 37.32 \\
7.69 & 36.94 & 38.68 & 39.32 & 39.34 & 39.56 & 39.26 & 36.67 & 33.72 & 35.43 \\
11.73 & 34.42 & 35.47 & 36.01 & 35.87 & 36.00 & 36.18 & 34.77 & 32.86 & 33.76 \\
16.04 & 33.61 & 34.37 & 34.70 & 34.29 & 34.47 & 34.83 & 33.72 & 32.19 & 33.03 \\
20.07 & 32.67 & 33.18 & 33.43 & 32.95 & 33.08 & 33.51 & 32.77 & 31.64 & 32.30 \\
24.12 & 31.52 & 31.85 & 32.00 & 31.60 & 31.69 & 32.07 & 31.63 & 30.88 & 31.35 \\
26.37 & 31.21 & 31.48 & 31.61 & 31.26 & 31.33 & 31.65 & 31.33 & 30.71 & 31.11 \\
29.07 & 30.89 & 31.08 & 31.17 & 30.82 & 30.88 & 31.20 & 30.97 & 30.50 & 30.85 \\
33.10 & 30.34 & 30.47 & 30.52 & 30.23 & 30.27 & 30.54 & 30.39 & 30.04 & 30.35 \\
37.01 & 29.68 & 29.74 & 29.75 & 29.50 & 29.52 & 29.75 & 29.67 & 29.45 & 29.72 \\
38.86 & 29.42 & 29.47 & 29.48 & 29.25 & 29.26 & 29.47 & 29.41 & 29.22 & 29.48 \\
40.82 & 29.22 & 29.25 & 29.25 & 29.03 & 29.04 & 29.23 & 29.18 & 29.03 & 29.28 \\
45.10 & 28.60 & 28.60 & 28.59 & 28.44 & 28.44 & 28.55 & 28.55 & 28.48 & 28.67 \\
48.80 & 28.45 & 28.45 & 28.42 & 28.29 & 28.28 & 28.40 & 28.39 & 28.33 & 28.52 \\
53.16 & 29.88 & 30.03 & 30.30 & 30.81 & 30.90 & 30.80 & 30.83 & 30.45 & 29.98 \\
\hline
\end{tabular}

\section{RESULTS}

Fig. 6 shows the results of validation of the proposed model with the experimental measurements. An average relative errors of $1.1 \%, 1.46 \%, 1.64 \%$ and $2.08 \%$ are recorded in the figure 5 ( $a, b, c$ and $d)$ respectively. It can be concluded from fig. 6 that there is a good agreement between numerical model and experimental results with varying inlet air temperature over time.

Fig. 7 presents the numerical solution of the proposed model for $24 \mathrm{~h}$ in continuous operation mode with constant inlet air temperature, the flowing air temperature $T_{a}$ inside the portions I and II (50 m total length) decreases when it flows more in the EAHE because of the underground thermal inertia. The coldness of the underground allows to the air to exchange its heat with soil. However, we observe an increasing in the air temperature at the last three meters of the EAHE, which corresponding to the vertical portion III, due to the increasing of the soil temperature. The same remark in outlet air temperature cited in fig. 8. Therefore, the flowing air temperature $T_{a}$ proportionally depends of the soil temperature. Based to the above results and in order to enhance the heat transfer between the air and the soil surrounding the pipe, a well sizing of the EAHE is important by taking into account several parameters (pipe length, pipe diameter, flow rate etc).

Fig. 8 presents the variation of the air temperature of inlet, outlet and three different sections (section 1,2 and 3) inside the EAHE at distances of $11.72 \mathrm{~m}, 33.1 \mathrm{~m}$, and $48.8 \mathrm{~m}$ from the pipe entrance respectively. Thus, fig. 8 shows the effect of continuous operation mode on the thermal performances of the EAHE. We notice that the air temperature presented in the sections 1 and 2 near the pipe entrance is unstable over time, because of the variation of the inlet temperature during the day. Besides, high temperatures in the day induce the accumulation of heat on the adjacent soil. After that, soil dissipates the stored heat to the next sub soil region during the night. On the other hand, the air temperature presented in the section 3 is almost constant and we did not record a noticeable effect of both inlet temperature and heat accumulation, which indicates that the initial $30 \mathrm{~m}$ of the pipe $(53 \mathrm{~m})$ provides almost $78 \%$ of the total air temperature drop, which means that the continuous operation mode does not affect the rest of the pipe during all the 71 hours of operation.

The input parameters used in figs. 9, 10 and 11 below are given in table 1.

Fig. 9 shows the temperature contours of air along the EAHE for different times under transient condition in continuous operation. Three different soil thermal conductivities $(0.5 \mathrm{w} / \mathrm{m} . \mathrm{K}, 1.25 \mathrm{w} / \mathrm{m} . \mathrm{K}, 4 \mathrm{w} / \mathrm{m} . \mathrm{K})$ are taken into account to evaluate the thermal performance of EAHE and to find the optimal soil thermal conductivity for burying the pipe. From fig. 9, it reveals that the thermal performance of EAHE is greatly affected by the soil thermal conductivity. The duration of operation ( 24 hours) has no remarkable effect on the soil of high thermal conductivity $\left(\lambda_{\text {soil }}=4\right.$ $\left.\mathrm{w} / \mathrm{m}^{\circ} \mathrm{c}\right)$, this effect appear clearly in soil with low thermal conductivity $\left(\lambda_{\text {soil }}=0.5 \mathrm{w} / \mathrm{m}^{\circ} \mathrm{c}\right)$.

Fig. 10 presents the air temperature drops along the EAHE under transient condition. Three different air flow velocities of $1 \mathrm{~m} / \mathrm{s}, 3.5 \mathrm{~m} / \mathrm{s}$ and $5 \mathrm{~m} / \mathrm{s}$ have been considered to study the effect of the duration of operation and air flow velocity on the thermal performance of EAHE. It is observed that the increasing of air flow velocity causes a decrease in air temperature drops, because of the decreasing residence time of the flowing air inside the EAHE. Therefore, the thermal performance deteriorates proportionally with increasing of air flow velocity. From fig 10 , we noticed that low air flow velocity $(1 \mathrm{~m} / \mathrm{s})$ and soil thermal conductivity of $1.25 \mathrm{w} / \mathrm{m}^{\circ} \mathrm{c}$ does not affect the thermal performance of EAHE during all the 24 hours.

Fig. 11 evaluates the derating factor calculated (on the basis of Eq. (15)) over time for different sections from pipe entrance under transient condition. The maximum air temperature observed from tables 3, 4 and 5 has been taken as a constant inlet air temperature in the calculation of derating factor. It is observed that the derating factor 
increases proportionally with the increasing of the duration of operation, this increasing is due to the continuous accumulation of heat on the adjacent soil of the pipe over time. Highest derating factor after $24 \mathrm{~h}$ of continuous operation is found equal to $46 \%$ at $5 \mathrm{~m}$ from pipe entrance. We concluded from fig. 11 that the initial $30 \mathrm{~m}$ of the pipe is greatly affected by the continuous operation of EAHE.

Fig. 12 shows the variation of thermal efficiency over time for a value of air velocity equal to $3.5 \mathrm{~m} / \mathrm{s}$. It is observed that the increasing of the difference between inlet air temperature and soil temperature leads to increase the thermal efficiency. The minimum thermal efficiency was recorded at night and can reach $9 \%$ when the inlet air temperature is low. The maximum value of thermal efficiency is $78.96 \%$ for inlet air temperature $\mathrm{T}_{\mathrm{ae}}=48.87^{\circ} \mathrm{C}$ measured at 15:30 (06/08/2013). Thus, the inlet air temperature plays a key role on the thermal efficiency.
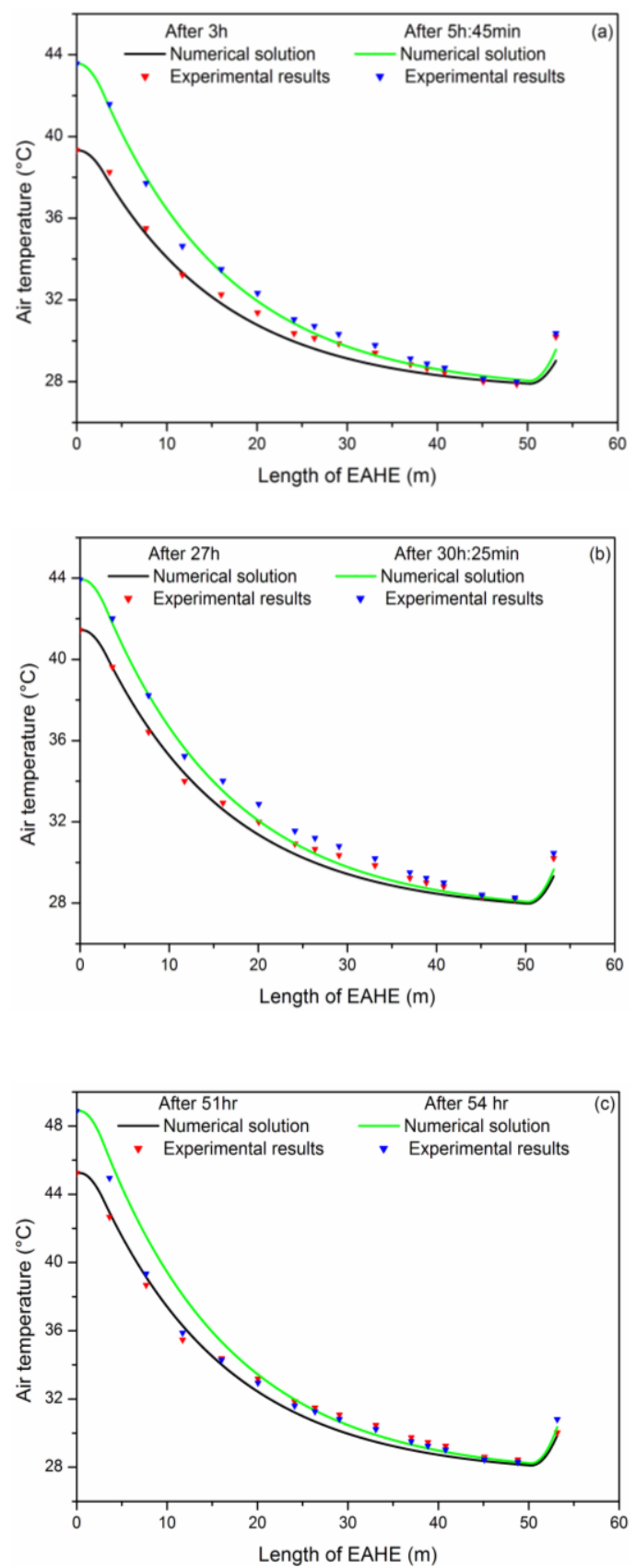

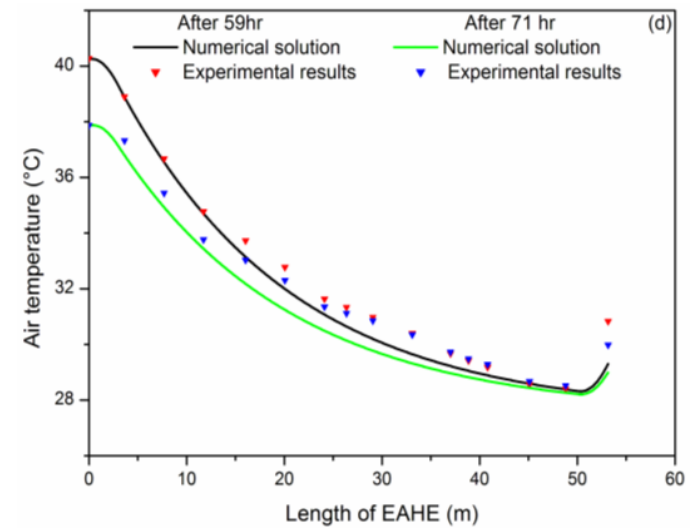

Figure 6. Air temperatures comparison between numerical solutions and experimental results: figs (a), (b), (c) and (d).

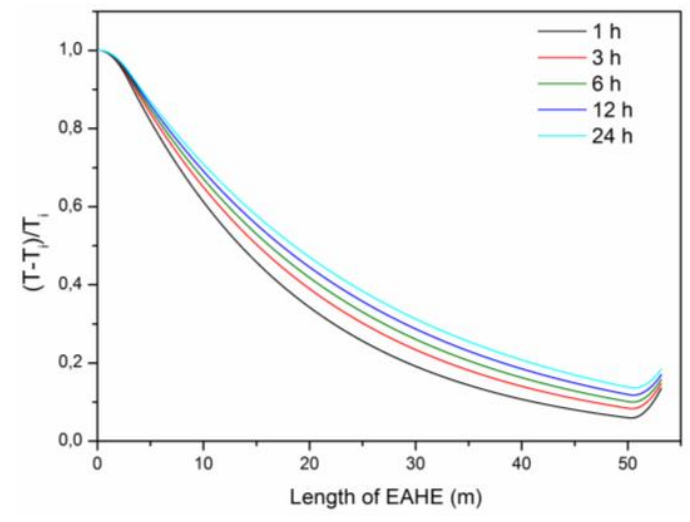

Figure 7. Graph of the present numerical solutions.

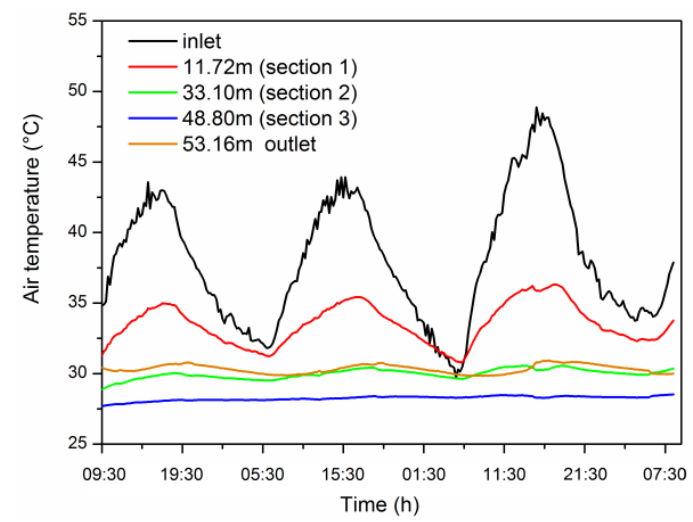

Figure 8. Values of air temperatures in different sections of the EAHE over time.

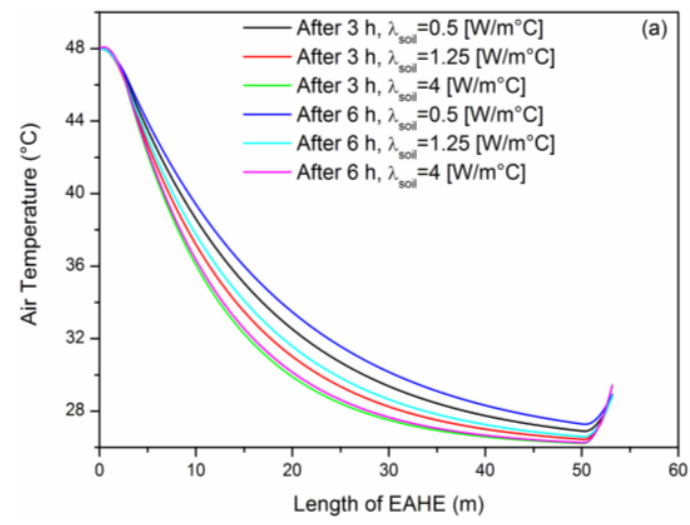




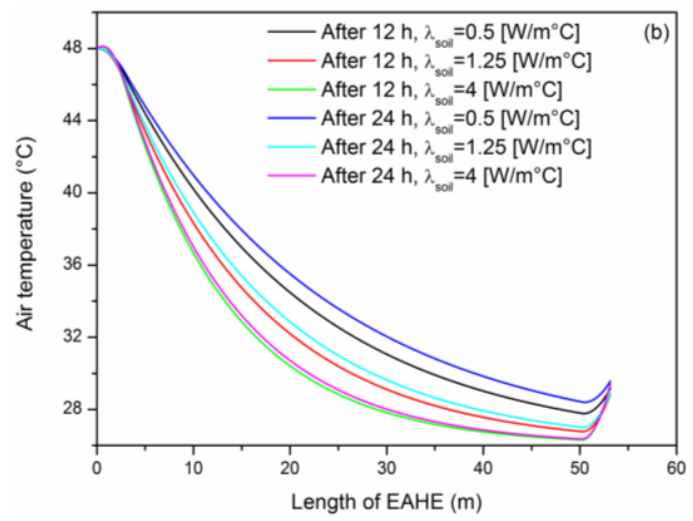

Figure 9. Hourly variation of air temperature along the EAHE for different soil thermal conductivities.
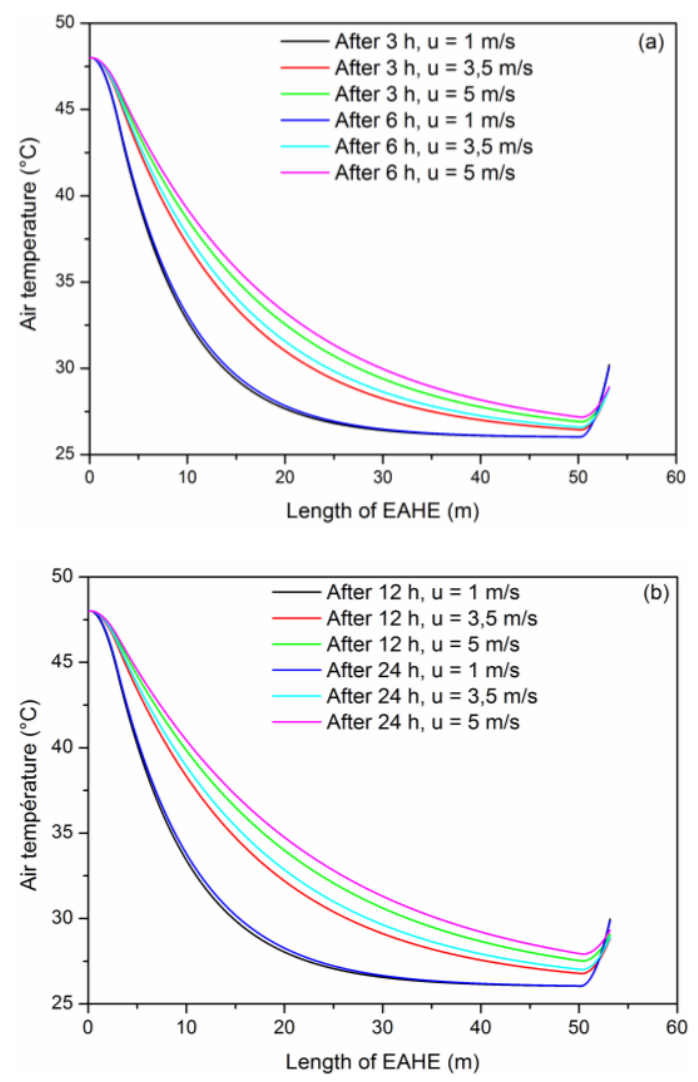

Figure 10. Hourly variation of air temperature along the EAHE for different air flow velocities.

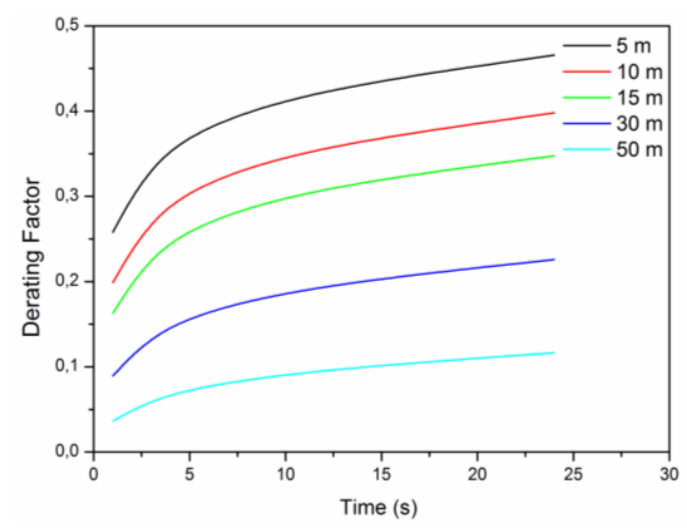

Figure 11. Variation in derating factor in different sections of the EAHE over time.

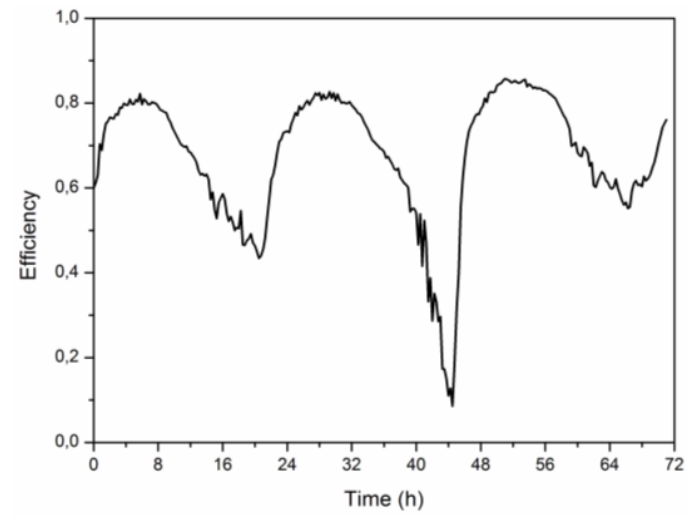

Figure 12. Variation of efficiency over time.

\section{CONCLUSION}

In this work, we presented in a detailed manner an experimental and numerical study of the air cooling using an earth air heat exchanger (EAHE). A transient onedimensional numerical model using finite differences method is proposed to determine the temperature distribution along the pipe. The model was compared with experimental measurements performed in the University of Biskra for three days in continuous operation mode. Maximum air temperature drop and maximum thermal efficiency of $18.06{ }^{\circ} \mathrm{C}$ and $78.96 \%$ respectively were achieved for high inlet air temperature $\left(48.87^{\circ} \mathrm{C}\right)$. The validation between numerical and experimental results shows a fair agreement with a maximum relative error of $7.46 \%$.

From this study the main concluding remarks are as follows: i) the Exploitation of the EAHE alone cannot give the thermal comfort of cooling. Consequently, it can reduce the electric power consumption like using the means of air conditioning. ii) in order that, the flowing air preserves its cool most possible in the vertical portion III, it must be ensure sufficient conditions of thermal insulation in this portion, iii) the continuous operation mode does not affect the thermal performances and outlet air temperature of the EAHE during all $71 \mathrm{~h}$ of operating for high soil thermal conductivities and low air flow velocities and iv) the initial $30 \mathrm{~m}$ of the pipe provides almost $78 \%$ of the total air temperature drop.

\section{ACKNOWLEDGMENTS}

The authors thank the University of Biskra for supporting the experimental research and the Laboratory of Mechanical Engineering LGM for financial support. We also thank Mebarek BAHRI for his contribution in writing this paper.

\section{REFERENCES}

[1] Scott N., Parsons R., Kochler T. (1965). Analysis and performance of an earth-air heat exchanger.

[2] Goswami D.Y., Ileslamlou S. (1990). Performance analysis of a closed-loop climate control system using underground air tunnel, Journal of Solar Energy 
Engineering, Vol. 112, No. 2, pp. 76-81. DOI: $10.1115 / 1.2929650$

[3] Bahadori M.N. (1978). Passive cooling systems in Iranian architecture, Scientific American, Inc., Vol. 238, No. 2, pp. 144-150,152,154. DOI: 10.1038/scientificamerican0278-144

[4] Bisoniya T.S., Kumar A., Baredar P. (2013). Experimental and analytical studies of earth-air heat exchanger (EAHE) systems in India: a review, Renewable and Sustainable Energy Reviews, Vol. 19 pp. 238-246. DOI: 10.1016/j.rser.2012.11.023

[5] Pfafferott J. (2003). Evaluation of earth-to-air heat exchangers with a standardised method to calculate energy efficiency, Energy and Buildings, Vol. 35 10, pp. 971-983. DOI: 10.1016/S0378-7788(03)00055-0

[6] Trombe A., Pettit M., Bourret B. (1991). Air cooling by earth tube heat exchanger: Experimental approach, Renewable Energy, Vol. 1, No. 5, pp. 699-707,. DOI: 10.1016/0960-1481(91)90016-I

[7] Thanu N.M., Sawhney R.L., Khare R.N., Buddhi D. (2001). An experimental study of the thermal performance of an earth-air-pipe system in single pass mode, Solar Energy, Vol. 71, No. 6, pp. 353-364. DOI: 10.1016/S0038-092X(01)00072-X

[8] Ghosal M.K., Tiwari G.N. (2006). Modeling and parametric studies for thermal performance of an earth to air heat exchanger integrated with a greenhouse, Energy Conversion and Management, Vol. 47, No. 13-14, pp. 1779-1798. DOI: $\underline{10.1016 / j . e n c o n m a n .2005 .10 .001}$

[9] Ghosal M.K., Tiwari G.N., Srivastava N.S.L. (2004). Thermal modeling of a greenhouse with an integrated earth to air heat exchanger: an experimental validation, Energy and Buildings, Vol. 36, No. 3, pp. 219-227, 2004. DOI: $10.1016 /$ j.enbuild.2003.10.006.

[10] Shukla A., Tiwari G.N., Sodha M.S. (2006). Thermal modeling for greenhouse heating by using thermal curtain and an earth-air heat exchanger, Building and Environment, Vol. 41, No. 7, pp. 843-850. DOI: 10.1016/j.buildenv.2005.04.014

[11] Sodha M.S., Sharma A.K., Singh S.P., Bansal N.K., Kumar A. (1985). Evaluation of an earth-air tunnel system for cooling/heating of a hospital complex, Building and Environment, Vol. 20, No. 2, pp. 115122. DOI: $10.1016 / 0360-1323(85) 90005-8$.

[12] Moummi N., Benfatah H., Hatraf N., Moummi A., Youcef-Ali S. (2010). Le rafraîchissement par la géothermie: étude théorique et expérimentale dans le site de Biskra, Revue des Energies Renouvelables, Vol. 13, No. 3, pp. 399-406.

[13] Trombe A., Serres L. (1994). Air-earth exchanger study in real site experimentation and simulation, Energy and Buildings, Vol. 21 2, pp. 155-162. DOI: $\underline{\text { 10.1016/0378-7788(94)90008-6. }}$

[14] Krarti M., Kreider J.F. (1996). Analytical model for heat transfer in an underground air tunnel, Energy Conversion and Management, Vol. 37, No. 10, pp. 1561-1574. DOI: $\underline{10.1016 / 0196-8904(95) 00208-1}$

[15] Hollmuller P. (2003). Analytical characterisation of amplitude-dampening and phase-shifting in air/soil heat-exchangers, International Journal of Heat and Mass Transfer, Vol. 46, No. 22, pp. 4303-4317. DOI: $\underline{10.1016 / \mathrm{S} 0017-9310(03) 00199-6}$
[16] Rouag A., Benchabane A., Labed A., Belhadj K., Boultif N. (2016). Applicability of a solar adsorption cooling machine in semiarid regions: proposal of supplementary cooler using earth-water heat exchanger, International Journal of Heat and Technology, Vol. 34, No. 2, pp. 281-286. DOI: 10.18280/ijht.340218

[17] Mihalakakou G., Santamouris M., Asimakopoulos D., I. Tselepidaki (1995). Parametric prediction of the buried pipes cooling potential for passive cooling applications, Solar Energy, Vol. 55, No. 3, pp. 163173. DOI: $10.1016 / 0038-092 \mathrm{X}(95) 00045-\mathrm{S}$

[18] Lee K.H., Strand R.K. (2008). The cooling and heating potential of an earth tube system in buildings, Energy and Buildings, Vol. 40, No. 4, pp. 486-494, 2008. DOI: 10.1016/j.enbuild.2007.04.003

[19] Brum R.S., Vaz J., Rocha L.A.O., dos Santos E.D., Isoldi L.A. (2013). A new computational modeling to predict the behavior of Earth-air heat exchangers, Energy and Buildings, Vol. 64, pp. 395-402. DOI: 10.1016/j.enbuild.2013.05.032

[20] Vaz J., Sattler M.A., dos Santos E.D., Isoldi L.A. (2011). Experimental and numerical analysis of an earth-air heat exchanger, Energy and Buildings, Vol. 43, No. 9, pp. 2476-2482. DOI: 10.1016/j.enbuild.2011.06.003

[21] Thiers S., Peuportier B. (2008). Thermal and environmental assessment of a passive building equipped with an earth-to-air heat exchanger in France, Solar Energy, Vol. 82, No. 9, pp. 820-831. DOI: $10.1016 /$ j.solener.2008.02.014

[22] Barakat S., Ramzy A., Hamed A.M., El Emam S.H. (2016). Enhancement of gas turbine power output using earth to air heat exchanger (EAHE) cooling system, Energy Conversion and Management, Vol. 111, pp. 137-146. DOI: $\underline{10.1016 / j . e n c o n m a n .2015 .12 .060}$

[23] Ozgener O., Ozgener L., Goswami D.Y. (2011). Experimental prediction of total thermal resistance of a closed loop EAHE for greenhouse cooling system, International Communications in Heat and Mass Transfer, Vol. 38, No. 6, pp. 711-716. DOI: 10.1016/j.icheatmasstransfer.2011.03.009

[24] Ozgener L. (2011). A review on the experimental and analytical analysis of earth to air heat exchanger (EAHE) systems in Turkey, Renewable and Sustainable Energy Reviews, Vol. 15, No. 9, pp. 4483-4490. DOI: $10.1016 /$ j.rser.2011.07.103

[25] Claesson J., Dunand A. (1983). Heat extraction from the ground by horizontal pipes: a mathematical analysis, BFR Swedish Council for Building Research

[26] Bansal V., Misra R., Agarwal G.D., Mathur J. (2013). Transient effect of soil thermal conductivity and duration of operation on performance of Earth Air Tunnel Heat Exchanger, Applied Energy, Vol. 103, pp. 1-11. DOI: $10.1016 /$ j.apenergy.2012.10.014

[27] Nilsson C.E. (1991). Preheating of ambient air by a system of earth tubes as a heat source for buildings, Chalmers University of Technology.

[28] Mihalakakou G., Lewis J.O., Santamouris M., On the heating potential of buried pipes techniques application in Ireland, Energy and Buildings, Vol. 24, No. 1, pp. 19-25, 1996. DOI: 10.1016/03787788(95)00957-4 
[29] Bojic M., Trifunovic N., Papadakis G., Kyritsis S. (1997). Numerical simulation, technical and economic evaluation of air-to-earth heat exchanger coupled to a building, Energy, Vol. 22, No. 12, pp. 1151-1158. DOI: $10.1016 / \mathrm{S} 0360-5442(97) 00055-8$

[30] Chel A., Janssens A., de Paepe M. (2015). Thermal performance of a nearly zero energy passive house integrated with the air-air heat exchanger and the earth-water heat exchanger, Energy and Buildings, Vol. 96, pp. 53-63. DOI: 10.1016/j.enbuild.2015.02.058

[31] Soni S.K., Pandey M., Bartaria V.N. (2015). Ground coupled heat exchangers: A review and applications, Renewable and Sustainable Energy Reviews, Vol. 47 pp. 83-92. DOI: 10.1016/j.rser.2015.03.014

[32] De Jesus Freire A., Alexandre J.L.C., Silva V.B., Couto N.D., Rouboa A. (2013). Compact buried pipes system analysis for indoor air conditioning, Applied Thermal Engineering, Vol. 51, No. 1-2, pp. 11241134. DOI: 10.1016/j.applthermaleng.2012.09.045

[33] Ozisik M.N. (1993). Heat Conduction, $2^{\text {nd }}$ Edition, John Wiley \& Sons.

[34] Al-Khoury R. (2011). Computational Modeling of Shallow Geothermal Systems, CRC Press.

[35] De Jesus Freire A., Alexandre J.L.C., Silva V.B., Couto N.D., A. Rouboa (2013). Compact buried pipes system analysis for indoor air conditioning, Applied Thermal Engineering, Vol. 51, No. 1, pp. 1124-1134. DOI: $10.1016 /$ j.applthermaleng.2012.09.045

[36] Diersch H.J.G., Bauer D., Heidemann W., Rühaak W., Schätzl P. (2011). Finite element modeling of borehole heat exchanger systems: Part 2. Numerical simulation, Computers \& Geosciences, Vol. 37, No. 8, pp. 1136-1147. DOI: $\underline{10.1016 / j . c a g e o .2010 .08 .002}$

[37] Mnasri T., Younès R.B. (2010). Modeling of unsteady turbulent flow in a buried co-axial exchanger-the use of Green's functions theory, Numerical Heat Transfer, Part A: Applications, Vol. 58, No. 12, pp. 963-983. DOI: 10.1080/10407782.2010.529031

[38] Philippe M., Bernier M., Marchio D. (2009). Validity ranges of three analytical solutions to heat transfer in the vicinity of single boreholes, Geothermics, Vol. 38, No. 4, pp. 407-413. DOI: 10.1016/j.geothermics.2009.07.002

[39] Belloufi Y., Brima A., Atmani R., Moummi N., Aissaoui F. (2016). Etude theorique et experimentale $\mathrm{du}$ rafraichissement de l'air par un echangeur geothermique AIR/SOL, LARHYSS Journal, Vol. 25, pp. 121-137.

[40] Aissaoui F., Benmachiche A.H., Brima A., Bahloul D., Belloufi Y. (2016). Experimental and Theoretical Analysis on Thermal Performance of the flat plate solar air collector, International Journal of Heat and
Technology, Vol. 34, No. 2, pp. 213-220. DOI: 10.18280/ijht.340209

[39] V. Bansal, R. Misra, G. D. Agarwal and J. Mathur, 'Derating Factor' new concept for evaluating thermal performance of earth air tunnel heat exchanger: A transient CFD analysis, Applied Energy, vol. 102 pp. 418-426, 2013. DOI: 10.1016/j.apenergy.2012.07.027.

[40] Belloufi Y., Brima A., Atmani R., Moummi N., Aissaoui F. (2016). Etude theorique et experimentale $\mathrm{du}$ rafraichissement de l'air par un echangeur geothermique AIR/SOL, LARHYSS Journal, Vol. 25, pp. 121-137.

[41] Aissaoui F., Benmachiche A.H., Brima A., Bahloul D., Belloufi Y. (2016). Experimental and Theoretical Analysis on Thermal Performance of the flat plate solar air collector, International Journal of Heat and Technology, Vol. 34, No. 2, pp. 213-220. DOI: $\underline{10.18280 / \text { ijht. } 340209}$

\section{NOMENCLATURE}

$\mathrm{T}_{\text {soil }} \quad$ soil temperature, ${ }^{\circ} \mathrm{C}$

$\mathrm{T}_{\mathrm{a}} \quad$ air temperature inside the EAHE, ${ }^{\circ} \mathrm{C}$

$\mathrm{T}_{\mathrm{ai}} \quad$ inlet air temperature, ${ }^{\circ} \mathrm{C}$

$\mathrm{T}_{\mathrm{a} 1} \quad$ outlet air temperature at the vertical portion $\mathrm{I},{ }^{\circ} \mathrm{C}$

$\mathrm{T}_{\mathrm{a} 2} \quad$ outlet air temperature at the horizontal portion II, ${ }^{\circ} \mathrm{C}$

$\mathrm{T}_{\mathrm{i}} \quad$ soil temperature at depth $\delta,{ }^{\circ} \mathrm{C}$

$\mathrm{u} \quad$ air velocity inside the pipe, $\mathrm{m} . \mathrm{s}^{-1}$

$\mathrm{h}$ convective heat transfer coefficient h, w.m $\mathrm{m}^{-2} \cdot{ }^{\circ} \mathrm{C}^{-1}$

$\mathrm{x} \quad$ Longitudinal coordinate, $\mathrm{m}$

$\mathrm{z} \quad$ vertical coordinate, $\mathrm{m}$

$\mathrm{r}_{1} \quad$ inner radius of the pipe, $\mathrm{m}$

$r_{2} \quad$ thickness of the pipe, $m$

$r_{3}$ adiabatic layer radius of the soil, $m$

1 length, $m$

$\mathrm{s}$ exchange surface, $\mathrm{m}^{2}$

$\mathrm{R} \quad$ thermal resistance, $\mathrm{m} . \mathrm{k} . \mathrm{w}^{-1}$

$\mathrm{m} \quad$ air mass, $\mathrm{kg}$

$\mathrm{c}_{\text {pair }} \quad$ specific heat, $\mathrm{j} \cdot \mathrm{kg}^{-1} \cdot{ }^{\circ} \mathrm{C}^{-1}$

$\mathrm{t}$ Time, $\mathrm{s}$

\section{Greek symbols}

$\lambda_{\text {soil }} \quad$ soil thermal conductivity, w.m $\mathrm{m}^{-1} \cdot{ }^{\circ} \mathrm{C}^{-1}$

$\alpha \quad$ soil thermal diffusivity, $\mathrm{m}^{2} \cdot \mathrm{s}^{-1}$

$\delta \quad$ penetration depth, $\mathrm{m}$

$\rho \quad$ air density, kg.m ${ }^{-3}$

$\varphi \quad$ heat flow, watt

\section{Abbreviations}

EAHE Earth air heat exchanger 